\title{
UTAUT Theory based User Acceptance Model of the Internet Financial and Empirical Study
}

\author{
Yan $\mathrm{Lu}$ \\ College of Information Science and Engineering \\ Shandong University of Science and Technology \\ Qingdao, P.R. China \\ luyan@sdkd.net.cn
}

\begin{abstract}
Exploring the key factors that influence users to accept the internet financial can help to promote the development of the internet financial business. In this paper, based on UTAUT (the Unified Theory of Acceptance and Use of Technology) theory, the author constructs the internet financial business acceptance model, which introduces factors of personal innovativeness and perceives risk, and designs a questionnaire. The credibility and effectiveness of the questionnaire are verified, and the correlations between factors of the model are attested. The author also establishes the regression equation between the factors to prove the rationality of the acceptance model proposed in this paper.
\end{abstract}

Keywords-Internet Financial; UTAUT; Acceptance Model; Personal Innovativeness; Perceived Risk

\section{INTRODUCTION}

The vigorous development of Internet technology has injected fresh energy to the financial industry. With the aid of big data, cloud computing and other advanced technology, the Internet financial business is bound to usher in rapid growth. Constructing of internet financial acceptance model and finding out the key factors that influence user acceptance of the Internet financial, will promote the development of internet finance scientifically.

The paper takes the users of Internet Financial as research object, their technology acceptance behavior as the research subject, and UTAUT (the Unified Theory of Acceptance and Use of Technology) model ${ }^{[1]}$ as the theoretical basis to explore the key influence factors of the users' acceptance of the Internet financial, and construct a technology acceptance model to help carrying out Internet financial business more efficiently. The main work of this paper includes the following three aspects: 1) introduce the technology acceptance theory into the internet financial acceptance research. In consideration of the characteristics of the Internet financial, introduce factors of personal innovativeness and perceived risk, and constructed user acceptance model of the internet financial. 2) Based on the model, relevant research hypotheses are put forward to and a questionnaire according to the research hypothes is is designed. 3) The credibility and effectiveness of the questionnaire are verified, and the regression relationships between the factors in the model are

\author{
Bing $\mathrm{Hu}$ \\ College of Information Science and Engineering \\ Shandong University of Science and Technology \\ Qingdao, P.R. China \\ binghu_1991@163.com
}

established to prove the rationality of the acceptance model proposed in this paper.

\section{USER ACCEPT ANCE MODEL OF THE INTERNET FINANCIAL}

The paper uses UTAUT as the theoretical basis to explore the key influence factors of the users' acceptance of the internet financial. Unified Theory of Acceptance and Use of Technology is an important branch of the information management research. Ven katesh improved the Technology Acceptance Model and put forward to UTAUT. UTAUT includes four core determinants (performance expectancy, effort expectancy, social influence and facilitating conditions) and four adjustment factors (gender, age, experience and voluntariness of use). UTAUT gained wide acceptance in academia, many scholars have made an extensive use of it in the field of information technology, e-commerce, cloud computing, electronic payment, mobile payment, biotechnology, teaching technologies etc. Sun Jianjun [ ${ }^{2]}$ made a comprehensive summary of the technology acceptance theory and proposed research direction. Min Qing $\mathrm{Fe}^{\left[{ }^{[3]}\right.}$ used the UTAUT model to study China's mobile e-commerce and established the user acceptance of mobile e-commerce model by introducing the factors of user satisfaction. Su Wan ${ }^{[4]}$ used UTAUT model to study the behavior of Internet of things in user acceptance.

Internet financial users suffer relatively weak influence of social environment, so the author discards the effects of social factors in the study, moreover, the adjustment factors of sex, age and user experience are not considered at present stage and will be considered in future work.

The model proposed in this paper is based on the study of the individual behavior of users. Therefore, the users' personal innovativeness is taken as an influence factor. June $\mathrm{Lu}^{[5]}$ believed that personal innovativeness and social influence had a significant positive effect on the research of user acceptance of wireless Internet based on mobile phone. Ioannis Karavasilis ${ }^{[6]}$ found out that personal innovativeness has a positive effect on the acceptance of the electronic government system of Greek teachers. Lan Junyao ${ }^{[7]}$ believed that personal innovativeness can enhance the user's curiosity about the new technology through the study of users' acceptance and use of mobile payments, which can stimulate the user to have a strong willingness to use new technology. 
Hypothesis 1: Personal innovativeness is positively correlated with behavioral intention.

Hypothesis 1a: Personal innovativeness has a significant impact on effort expectation.

In the UTAUT model, effort expectation is a measure of the degree of difficulty that a user has experienced in using a system. And when effort expectation is introduced into the internet financial service, it is the degree of difficulty that a user has experienced in using the internet financial business.

Hypothesis 2: Effort expectation is positively correlated with behavioral intention.

Performance expectation is the measurement of the performance for the use of a system. When users find that the system has a positive impact on their work, it would be easier to accept it.

Hypothes is 3: Performance expectation is positively correlated with behavioral intention.

Perceived risk is first extended from the perspective of psychology. Pavlou ${ }^{[8]}$ found out that perceived risk had a significant impact on the acceptance of electronic commerce in his study of the e-commerce user acceptance behavior. Similarly, Lou Jie ${ }^{[9]}$ found out that the lower risk individuals can perceive, the more positive attitude they would have towards online shopping. Cui Yanhong ${ }^{[10]}$ also introduced the theory of perceived risk to online shopping, she believed that online shopping providers should pay attention to perceived risk and take positive measures to reduce the risk perceived by online shoppers.

Hypothesis 4: Perceived risk is negatively related to user's behavioral intention.

Facilitating conditions here is correlated with the convenience, which includes the hardware and software provided by the service provider and the network environment. Furthermore, behavioral intention has a positive impact on the using of the behavior.

Hypothes is 5: Facilitating conditions is positively correlated with both behavioral intention and using behavior.

Hypothesis 6: Behavioral intention is positively correlated with using behavior. Based on the above hypothesis, the user acceptance model of internet financial can be seen in Fig. 1:

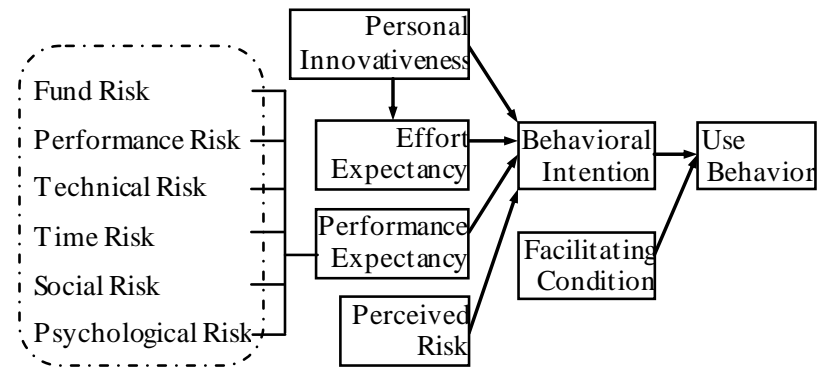

Figure 1. Hypothesis Model

\section{EMPIRICAL STUDY}

The paper designs a questionnaire. The first part of the questionnaire is the basic information of the surveyed user, mainly including internet financial experience, gender, age, level of education etc. The second part are factors affecting the model, containing four questions of personal innovativeness, three questions of effort expectation, four questions of performance expectations, six questions of perceived risk, five questions of facilitating conditions, three questions of behavioral intention and three questions of use behavior. The survey is conducted online and offline simultaneously, and received 324 valid questionnaires. Specific sample characteristics are shown in TABLE I.

TABLE I. INTERNET FINANCIAL BUSINESS USAGE STATISTICS

\begin{tabular}{|l|c|c|}
\hline \multicolumn{1}{|c|}{ Category } & Number & Proportion \\
\hline Online bank & 297 & $91.67 \%$ \\
\hline Third party payment & 210 & $64.81 \%$ \\
\hline P2P net loan & 28 & $8.64 \%$ \\
\hline All the chips & 17 & $5.25 \%$ \\
\hline Financial products & 207 & $63.89 \%$ \\
\hline Internet lottery & 108 & $33.33 \%$ \\
\hline Internet decurities trading & 23 & $7.10 \%$ \\
\hline Internet insurance & 30 & $9.26 \%$ \\
\hline Other internet financial services & 19 & $5.86 \%$ \\
\hline
\end{tabular}

A. Reliability Analysis

TABLE II. CRONBACH'S a

\begin{tabular}{|c|c|c|c|}
\hline Factor & $\begin{array}{c}\text { Question } \\
\text { Item }\end{array}$ & $\begin{array}{c}\text { a AfterDelete } \\
\text { Question }\end{array}$ & $\begin{array}{c}\text { Cranbach's } \\
\text { a } \\
\end{array}$ \\
\hline \multirow{4}{*}{$\begin{array}{l}\text { Personal } \\
\text { Innovativeness }\end{array}$} & PI1 & .719 & \multirow{4}{*}{.791} \\
\hline & PI2 & .783 & \\
\hline & PI3 & .745 & \\
\hline & $\mathrm{PI} 4$ & .706 & \\
\hline \multirow{3}{*}{$\begin{array}{l}\text { Effort } \\
\text { Expectation }\end{array}$} & EE1 & .791 & \multirow{3}{*}{.875} \\
\hline & EE2 & .808 & \\
\hline & EE3 & .869 & \\
\hline \multirow{4}{*}{$\begin{array}{l}\text { Performance } \\
\text { Expectations }\end{array}$} & PE1 & .885 & \multirow{4}{*}{.908} \\
\hline & PE2 & .886 & \\
\hline & PE3 & .878 & \\
\hline & PE4 & .872 & \\
\hline \multirow{6}{*}{$\begin{array}{l}\text { Perceived } \\
\text { Risk }\end{array}$} & PR1 & .812 & \multirow{6}{*}{.852} \\
\hline & PR2 & .823 & \\
\hline & PR3 & .849 & \\
\hline & PR4 & .830 & \\
\hline & PR5 & .830 & \\
\hline & PR6 & .815 & \\
\hline \multirow{5}{*}{$\begin{array}{l}\text { Facilitating } \\
\text { Conditions }\end{array}$} & $\mathrm{FC} 1$ & .884 & \multirow{5}{*}{.899} \\
\hline & FC2 & .872 & \\
\hline & FC3 & .873 & \\
\hline & FC4 & .879 & \\
\hline & FC5 & .876 & \\
\hline \multirow{3}{*}{$\begin{array}{l}\text { Behavioral } \\
\text { Intention }\end{array}$} & INT 1 & .826 & \multirow{3}{*}{.890} \\
\hline & INT2 & .815 & \\
\hline & INT3 & .887 & \\
\hline \multirow{3}{*}{$\begin{array}{l}\text { Use } \\
\text { Behavior }\end{array}$} & ACT 1 & .825 & \multirow{3}{*}{.864} \\
\hline & ACT 2 & .787 & \\
\hline & ACT3 & .815 & \\
\hline \multicolumn{3}{|c|}{ Total variables } & 887 \\
\hline
\end{tabular}


The questionnaire data is analyzed with SPSS2.0. The reliability analysis is conducted with $\alpha$ reliability coefficient method, and the coefficient of determination is Cronbach's alpha.

When the value of Cronbach's alpha is greater than 0.5 , it is considered as a trusted questionnaire. It can be seen from TABLE II that the Cronbach's alpha of each variable is greater than 0.79 , and the Cronbach's alpha of every factor decreases after deleting the question items. The overall reliability of the scale is 0.887 .

\section{B. Validity Analysis}

Method of construct validity is used to analyze the validity. The paper uses the factor analysis of principal component analysis to verify the validity. KMO (KaiserMeyer-Olkin) and Bartlett test are usually required before factor analysis. The results are shown in TABLE III.
TABLE III. KMO AND BARTLETT'S TEST OF SPHERICITY

\begin{tabular}{|l|c|c|c|c|c|}
\hline \multirow{2}{*}{ Factor } & \multirow{2}{*}{$\begin{array}{c}\text { Number of } \\
\text { Questions }\end{array}$} & \multirow{2}{*}{ KMO } & \multicolumn{3}{|c|}{ Bartlett Sphere Test } \\
\cline { 4 - 6 } & $\begin{array}{c}\text { Approximate } \\
\text { chi-square }\end{array}$ & Freedom & Sig. \\
\hline $\begin{array}{l}\text { Personal } \\
\text { Innovativeness }\end{array}$ & 4 & .773 & 381.126 & 6 & .000 \\
\hline $\begin{array}{l}\text { Effort } \\
\text { Expectation }\end{array}$ & 3 & .728 & 511.375 & 3 & .000 \\
\hline $\begin{array}{l}\text { Performance } \\
\text { Expectations }\end{array}$ & 4 & .818 & 864.214 & 6 & .000 \\
\hline Perceived Risk & 6 & .885 & 726.501 & 15 & .000 \\
\hline $\begin{array}{l}\text { Facilitating } \\
\text { Conditions }\end{array}$ & 5 & .867 & 948.548 & 10 & .000 \\
\hline $\begin{array}{l}\text { Behavioral } \\
\text { Intention }\end{array}$ & 3 & .734 & 573.788 & 3 & .000 \\
\hline Use Behavior & 3 & .734 & 459.957 & 3 & .000 \\
\hline
\end{tabular}

Note: 0 of significant indicates that significant level is below 0.001

TABLE IV. TOTAL VARIANCE EXPLAINED

\begin{tabular}{|c|c|c|c|c|c|c|c|c|c|}
\hline \multirow{2}{*}{ Factor } & \multicolumn{3}{|c|}{ Initial Eigenvalues } & \multicolumn{3}{|c|}{ Extraction Sums of squaredLoadings } & \multicolumn{3}{|c|}{ Rotation Sums of Squared Loadings } \\
\cline { 2 - 11 } & Total & \% of Variance & Cumulative\% & Total & \% of Variance & Cumulative\% & Total & variance\% & Cumulative \% \\
\hline 1 & 15.827 & 56.525 & 56.525 & 15.827 & 56.525 & 56.525 & 5.846 & 20.880 & 20.880 \\
\hline 2 & 1.260 & 4.501 & 61.026 & 1.260 & 4.501 & 61.026 & 5.213 & 18.618 & 39.498 \\
\hline 3 & 1.130 & 4.036 & 65.062 & 1.130 & 4.036 & 65.062 & 4.125 & 14.732 & 54.230 \\
\hline 4 & 1.021 & 3.645 & 68.706 & 1.021 & 3.645 & 68.706 & 4.053 & 14.476 & 68.706 \\
\hline
\end{tabular}

From TABLE III, it can be seen that the KMO values of all factors are more than 0.7 , and the Bartlett spherical test are significantly different. So the factors of questionnaire can be kept. Through principal component factor analysis, the cumulative contribution rate of factor extraction is obtained and shown in TABLE IV. From TABLE IV , it can be seen that four factors are obtained. And all of the initial eigenvalues are greater than 1 . The explanations of four factors have reached $68.706 \%$. Therefore, construct validity is acceptable.

\section{Regression Analysis}

TABLE V. MODEL SUMMARY ${ }^{\mathrm{E}}$

\begin{tabular}{|c|c|c|c|c|c|}
\hline Model & $\mathbf{R}$ & \begin{tabular}{|c|} 
R \\
Square
\end{tabular} & $\begin{array}{l}\text { Adjusted } \\
\text { R Square }\end{array}$ & $\begin{array}{l}\text { Std. Error of } \\
\text { the Estimate }\end{array}$ & $\begin{array}{c}\text { Durbin } \\
- \text { Watson }\end{array}$ \\
\hline 1 & $.808^{\mathrm{a}}$ & .653 & .652 & .46444 & \\
\hline 2 & $.855^{\mathrm{b}}$ & .731 & .729 & .40977 & \\
\hline 3 & $.870^{\mathrm{c}}$ & .756 & .754 & .39037 & \\
\hline 4 & $.878^{\mathrm{d}}$ & .770 & .767 & .37954 & 1.562 \\
\hline \multicolumn{6}{|c|}{ a. Predictive variable: (Constant), Effort expectation $。$} \\
\hline \multicolumn{6}{|c|}{$\begin{array}{l}\text { b.Predictive variable: (Constant), Effort expectation, Perceived } \\
\text { risk. }\end{array}$} \\
\hline \multicolumn{6}{|c|}{$\begin{array}{l}\text { c. Predictive variable: (Constant), Effort expectation, Perceived risk } \\
\text { Performance expectations。 }\end{array}$} \\
\hline \multicolumn{6}{|c|}{$\begin{array}{l}\text { d. Predictive variable: (Constant), Effort expect ation, Perceived risk, } \\
\text { Performance expectations, Personal innovativeness }\end{array}$} \\
\hline
\end{tabular}

Before regression analysis, the paper measures correlation degree of each influencing factor through the Spearman Correlation Coefficient. The results show that facilitating conditions and behavioral intention have significant correlation with using behavior, personal innovativeness, effort expectancy and performance expectations have significant correlation with behavioral intention, perceived risk has significant negative correlation with behavioral intention, personal innovativeness have significant positive correlation with effort expectations.

Then the paper carries out a regression analysis with behavioral intention (INT) as the dependent variable.

TABLE VI. ANOVA ${ }^{A}$

\begin{tabular}{|c|c|c|c|c|c|c|}
\hline & Model & $\begin{array}{c}\text { Sum of } \\
\text { Squares } \\
\end{array}$ & Freedom & $\begin{array}{c}\text { Mean } \\
\text { Square } \\
\end{array}$ & $\mathbf{F}$ & Sig. \\
\hline \multirow{3}{*}{1} & Regression & 130.549 & 1 & 130.549 & 605.208 & $.000^{6}$ \\
\hline & Residual & 69.458 & 322 & .216 & & \\
\hline & Total & 200.007 & 323 & & & \\
\hline \multirow{3}{*}{2} & Regression & 146.107 & 2 & 73.054 & 435.075 & $.000^{\mathrm{c}}$ \\
\hline & Residual & 53.899 & 321 & .168 & & \\
\hline & Total & 200.007 & 323 & & & \\
\hline \multirow{3}{*}{3} & Regression & 151.243 & 3 & 50.414 & 330.835 & $.000^{\mathrm{C}}$ \\
\hline & Residual & 48.763 & 320 & .152 & & \\
\hline & Total & 200.007 & 323 & & & \\
\hline \multirow{3}{*}{4} & Regression & 154.054 & 4 & 38.513 & 267.354 & $.000^{\mathrm{e}}$ \\
\hline & Residual & 45.953 & 319 & .144 & & \\
\hline & Total & 200.007 & 323 & & & \\
\hline \multicolumn{7}{|c|}{ a. Dependent variable: Behavioral intention } \\
\hline \multicolumn{7}{|c|}{ b. Predictive variable: (Constant),Effort expectation。 } \\
\hline \multicolumn{7}{|c|}{ c. Predictive variable: (Constant), Effort expectation, Perceived risk 。 } \\
\hline \multicolumn{7}{|c|}{$\begin{array}{l}\text { d. Predictive variable: (Constant), Effort expectation, Perceived risk, } \\
\text { Performance expectations . }\end{array}$} \\
\hline \multicolumn{7}{|c|}{$\begin{array}{l}\text { e. Predictive variable: (Constant), Effort expectation, Perceived risk, } \\
\text { Performance expectations, Personal innovativeness 。 }\end{array}$} \\
\hline
\end{tabular}

It can be seen from Table $\mathrm{V}$ that $\mathrm{R} 2=0.770$ and adjusted $R 2=0.767$, which can explain $76.7 \%$ variation. In Table VI, $\mathrm{F}=267.354$ and $\mathrm{Sig}=0.000<0.001$, so 
personal innovativeness, effort expectation, performance expectations and perceived risk have significant correlation with behavioral intension.

TABLE VII. COEFFICIENT

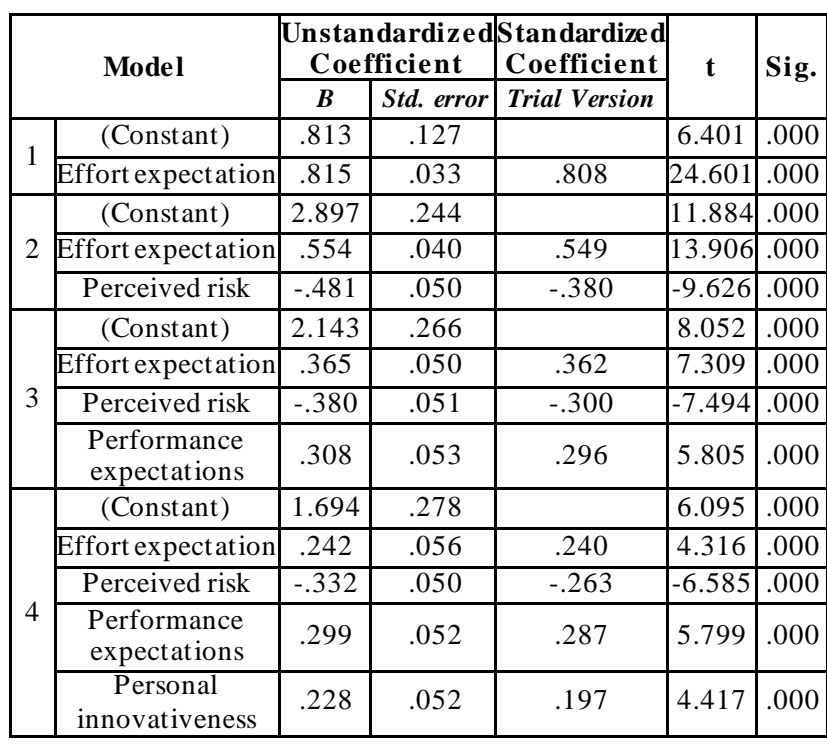

In TABLE VII, the prediction of behavioral intention by effort expectation is significant when $\mathrm{t}=4.316$ and Sig $=0.000<0.001$, the prediction of behavioral intention by perceived risk is significant when $t=-6.585$ and $\mathrm{Sig}=0.000<0.001$, the prediction of behavioral intention by performance expectations is significant when $t=5.799$ and $\mathrm{Sig}=0.000<0.001$, and the prediction of behavioral intention by personal innovativeness is significant when $\mathrm{t}=4.417$ and $\mathrm{Sig}=0.000<0.001$. The regression equation can be obtained which takes behavioral intention as the dependent variable:

Behavioral Intention $=0.197 \times$ Pers onal

Innovativeness $+0.240 \times$ Effort Expectation $+0.287 \times$

Performance Expectations $-0.263 \times$ Perceived Risk (1)

By (1), it can be confirmed that Hypothesis 1, 2, 3 and 4 are correct. In the same way, set up regression equation (2) which takes using behavior as the dependent variable, and (3) which takes Effort Expectation as the dependent variable.

Use Behavior $=0.834 \times$ Behavioral Intention $+0.129 \times$

Facilitating Conditions

Effort Expectation $=0.785 \times$ Personal Innovativeness (3)

By (2) and (3), it can be confirmed that Hypothesis 5, 6 and $1 \mathrm{a}$ are correct.

\section{CONCLUSIONS AND FUTURE WORK}

Based on UTAUT theory model, this paper studies the influencing factors of internet financial users' acceptance behavior, mainly including personal innovativeness, performance expectancy, effort expectancy, perceived risk and facilitating conditions. The paper designs a questionnaire. The credibility and effectiveness of the questionnaire are verified, and the correlations between factors of the model are attested. The paper also establishes the regression equation between the factors to prove the rationality of the acceptance model proposed in this paper. Because of the characteristics of internet financial, the research mainly focuses on individual user's acceptance behavior, therefore, ignoring some adjustment factors such as experience, age, gender etc. Thus, there are some deficiencies. Future work is to enrich the theoretical model by introducing more external factors, so that it will have a wider applicability.

\section{ACKNOWLEDGMENT}

This work was supported by the National Natural Science Foundation of China (No.70673098).

\section{REFERENCES}

[1] J.V.Venkatesh, M.G.Morris, B. D. Gordon and F. D. Davis, "User Acceptance of Information Technology: Toward a Unified View", Journal of MIS Quarterly. vol. 3. pp425-478, 2003.

[2] J.J.Sun, Y.Cheng and Q.Qing, "Advances of Research on Technology Acceptance Model, Journal of Information Science”, vol. 8. pp1121-1127,2007.

[3] J.Q.Min, S.Ji and G.Qu, Mobile Commerce User Acceptance Study in China : A Revised UTAUT Model, Journal of T singhua Science \& T echnology. vol. 3.pp257-264, 2008.

[4] J.W. Su, X. Bi and L. Wang, "Research on User Acceptance Model of Internet of Things Based on UTAUT Theory", Journal of Information Science. vol. 5. pp128-132, 2013.

[5] J.J.Lu, J.E. Yao and C.S.Yu, "Personal Innovativeness, Social Influences and Adoption of Wireless Internet Services via Mobile Technology", Journal of Strategic Information Systems. 2005.

[6] J.I.Karavasilis, K.Zafiropoulos and V.Vrana, "TAM to Understand E-governance Adoption by Teachers in Greece", Journal of Communications in Computer \& Information Science. pp57-68, 2010.

[7] D.J.Lan, "Research on the Factors Influencing Mobile Payment Behavior of Young Users", Central China Normal University, 2012.

[8] J.P.A.Pavlou, "Consumer Acceptance of Electronic Eommerce: Integrat ing trust and risk with the technology accept ance model", International Journal of Electronic Commerce. vol. 3. pp 101-34, 2013.

[9] D.J.Lou, "A Study of Determining Factors on Internet Purchasing and Its Process", Zhejiang University, 2006.

[10] J.Y.Cui, "Application of Perceived Risk Theory in Online Shopping”, E-Business Journal. vol. 3.pp75-79, 2007. 